\title{
UPACARA ADAT RUWATAN BUMI DI KELURAHAN WINONGO KECAMATAN MANGUHARJO KOTA MADIUN ( LATAR SEJARAH, NILAI-NILAI FILOSOFIS, DAN POTENSINYA SEBAGAI SUMBER PEMBELAJARAN SEJARAH LOKAL)
}

\author{
Ilham Abadi \& Soebijantoro*
}

\begin{abstract}
Abstrak
Penelitian ini bertujuan untuk menganalisis dan mendeskripsikan latar belakang sejarah upacara adat ruwatan bumi, nilai-nilai filosofis, dan potensinya sebagai sumber pembelajaran sejarah lokal, lokasi penelitian ini berada di Kelurahan Winongo, Kecamatan Manguharjo, Kota Madiun.

Metode yang digunakan dalam penelitian ini adalah pendekatan kualitatif dengan jenis deskriptif. Sumber data yang digunakan dalam penelitian ini adalah sumber data primer dan sumber data sekunder. Teknik pengumpulan data dengan cara wawancara, observasi dan dokumentasi/arsip. Sedangkan validasi yang digunakan untuk menguji kebenaran data menggunakan trianggulasi sumber penelitian. Analisis data menggunakan model interaktif Milles dan Huberman.

Dari penelitian yang telah dilaksanakan menunjukkan hasil bahwa upacara adat ruwatan bumi di Kelurahan Winongo Kecamatan Manguharjo Kota Madiun sudah ada sejak jaman kerajaan Mataram, karena Madiun merupakan daerah kekuasaan kerajaan tersebut. Tradisi tersebut kemudian selalu diperingati setiap satu tahun sekali berkenaan dengan pelestarian kebudayaan nenek moyang dan penghormatan kepada Tuhan Yang Maha Esa. Keberadaan upacara adat ruwatan bumi tersebut memiliki nilai-nilai filosofis ditinjau dari prosesi dan perlengkapan yang digunakannya, diantaranya semangat bekerja keras, hemat, rasa syukur atas nikmat Tuhan Yang Maha Esa, pelestarian kebudayaan nenek moyang. Upacara adat ruwatan bumi di Kelurahan Winongo Kecamatan Manguharjo Kota Madiun memiliki sebagai sumber pembelajaran sejarah lokal, dikarenakan pengetahuan yang dapat diambil dari kegiatan tersebut, ditinjau dari beberapa aspek dapat disesuaikan dengan materi pembelajaran sejarah yang ada dalam dunia pendidikan.
\end{abstract}

\section{Kata Kunci: Upacara Adat, Sejarah, Nilai-nilai Filosofis, Sumber Pembelajaran, Sejarah Lokal}

\section{Pendahuluan}

Sebagai bangsa yang majemuk, Indonesia memiliki dua macam sistem budaya yang sama-sama harus dipelihara dan dikembangkan, yakni sistem budaya nasional dan sistem budaya etnik lokal. Sistem budaya nasional adalah sesuatu yang relatif baru dan sedang berada dalam proses pembentukannya. Kebudayaan menjadi cermin besar yang menggambarkan peradaban suatu bangsa. (Zulianti dan Hanif.2012:43)

Kebudayaan yang dimiliki bangsa Indonesia adalah merupakan kebiasaan atau tradisi turun temurun yang kemudian ditirukan dan diteruskan oleh generasi berikutnya. Banyak mitologi yang mewarnai kehidupan masyarakat tradisional Indonesia, seperti halnya yang diyakini masyarakat Jawa yang dikenal dengan kejawennya, suatu tradisi yang cenderung mistis dan dilestarikan oleh masyarakat jawa."Kepercayaan yang ada dalam masyarakat Jawa ini memiliki keragaman yang banyak sekali, baik berbentuk ritual atau upacara, maupun hal-hal lain yang bersifat spiritual" (Pamungkas, 2008:1). Keragaman kegiatan ini terus dijalankan karena dianggap memiliki makna oleh sebagian masyarakat khususnya masyarakat Jawa. 
Di era globalisasi seperti saat ini, masyarakat yang cenderung berpikiran logis daripada mistis telah mulai meninggalkan tradisi yang dilaksanakan secara turun temurun tersebut. Tidak jarang masyarakat justru menganganggapnya sebagai sebuah cerita tradisional yang tidak bermakna tanpa perlu untuk meyakini dan melestarikannya. Hal tersebut dikarenakan masyarakat merasa apa yang ada di dalam tradisi tersebut tidak memiliki pengaruh terhadap kehidupannya. Selain itu, muncul dan berkembangnya teknologi juga membuat sebagian besar masyarakat kita meninggalkan sebuah tradisi. Upacara tradisional contohnya, yang bagi sebagian orang juga dikaitkan dengan pemenuhan kebutuhan spiritual kini mulai ditinggalkan oleh masyarakat kita, khususnya di perkotaan karena dinilai tidak logis bagi kehidupan yang serba modern ini.

Di wilayah Kota Madiun sendiri yang notabene merupakan kawasan cukup maju diberbagai bidangnya ternyata masih terdapat satu kelurahan yang menjalankan upacara adat yang di wariskan oleh masyarakat terdahulu dan prosesinya dilaksanakan setiap tahun serta dikemas secara meriah. Tradisi yang di dalamnya memiliki beberapa prosesi adat tersebut dinamakan upacara adat ruwatan bumi, dan dilaksanakan dari semua kalangan warga masyarakat Kelurahan Winongo.

Upacara adat ruwatan bumi di Kelurahan Winongo ini adalah salah satu upacara adat Jawa yang menarik untuk dikaji terkait, karena meskipun rutin diadakan setiap tahunnya, masih banyak masyarakat yang belum mengetahui secara pasti tentang latar belakang sejarah, nilai-nilai filosofis yang terkandung, serta potensinya sebagai sumber pembelajaran sejarah lokal. penulisan sejarah lokal memungkinkan kita untuk berhubungan secara sangat intim dengan peristiwa yang sangat lokal dan mungkin selama ini dianggap tidak besar, tetapi sesungguhnya memiliki peran penting dan berharga dalam membentuk peristiwa yang lebih besar.

Satu hal yang perlu dicatat di era otonomi seperti saat ini adalah sangat pentingnya sejarah lokal bagi pembelajaran suatu daerah, pemanfaatan sejarah lokal di tingkat pendidikan manapun akan memungkinkan peserta didik dalam mempelajari sejarah dapat beresonansi dengan aspek eigenwelt yang dimiliki. Sepengetahuan penulis, penelitian ini belum banyak dilakukan, Untuk itu penelitian mengenai upacara adat ruwatan bumi di Kelurahan Winongo Kecamatan Manguharjo Kota Madiun ini menarik untuk di teliti lebih dalam.

\section{Tujuan Penelitian}

Dalam mengadakan penelitian tidak terlepas dari tujuan yang hendak dicapai, sebab tujuan penelitian tersebut akan member arah dalam penelitian. Adapun yang menjadi tujuan penelitian adalah, untuk mendeskripsikan latar belakang sejarah, menjelaskan proses pelaksanaan, menganalisis nilai-nilai filosofis, serta menjelaskan potensi dari upacara adat ruwatan bumi di kelurahan Winongo kecamatan Manguharjo kota Madiun yang dapat digunakan sebagai sumber pembelajaran sejarah lokal.

\section{Kajian Pustaka}

\section{A. Upacara Adat Ruwatan Bumi}

1. Pengertian Upacara Adat Ruwatan Bumi Kegiatan masyarakat Jawa yang berhubungan dengan kepercayaan lama masih banyak yang mempercayainya terutama yang berhubungan dengan tradisi yang sering mereka laksanakan pada harihari tertentu menurut kepercayaan Jawa seperti upacara. Upacara ialah rangkaian tindakan atau perbuatan yang terikat pada aturan-aturan tertentu menurut adat atau agama. Biasanya perayaan atau serangkaian kegiatan tersebut dilaksanaka sehubungan dengan peristiwa penting dalam kehidupan manusia.

Purwadi (2005:1) menjelaskan bahwa upacara merupakan salah satu wujud peninggalan kebudayaan. Kebudayaan adalah warisan sosial yang hanya dapat dimiliki oleh warga masyarakat pendukungnya dengan jalan mempelajarinya. Ada caracara atau mekanisme tertentu dalam tiap 
masyarakat untuk memaksa tiap warganya mempelajari kebudayaan yang di dalamnya terkandung norma-norma serta nilai-nilai kehidupan yang berlaku dalam tata pergaulan masyarakat yang bersangkutan

Sistem upacara religius bertujuan mencari hubungan manusia dengan Tuhan, dewa-dewa atau makluk halus yang mendiami alam gaib. Sistem upacara merupakan wujud kelakuan atau behavioral manifestation dari religi. Dimana upacara terdiri dari kombinasi dari macam unsur upacara, seperti misalnya: berdoa, bersujud, bersaji, berkorban, makan bersama, menari, dan menyanyi, berprosesi, berseni drama suci, berpuasa, bertapa, dan bersemadi. Dapat diperjelas bahwa setiap unsur yang terkandung dalam upacara selalu diadakan sebagai syarat atau perlengkapan disetiap penyelenggaraan upacara adat. Hal tersebut dimaksudkan supaya tidak terjadi hal yang tidak diinginkan. (Satoto,2008:44)

Upacara adat adalah ritual yang dilakukan untuk menghindarkan diri dari dampak yang ditimbulkan akibat kesalahan manusia. (Pamungkas, 2008:3). Hal serupa juga diutarakan oleh Kamajaya bahwa Upacara adat sebagai ungkapan hasil penghayatan hidup bermasyarakat Upacara adat menyadarkan kita melalui pesan-pesan simbolik bahwa dalam kehidupan manusia itu berlaku hukum adi kodrati yang bersifat mutlak dan langgeng (Kamajaya,1992:2).

Upacara adat merupakan tradisi yang mengajarkan agar kita sebagai manusia berbudaya ikut bertanggung jawab menjaga kelestarian alam seisinya, ikut meningkatkan harkat dan martabat manusi adalam berbagai upaya, turut membina kerukunan bermasyarakat, berdasarkan keyakinan bahwa upaya dan tindakannya sesuai dengan hukum adi kodrati yang berlaku bagi setiap umat. Penyampaian pesan secara simbolik melalui penyelenggaraan upacara adat dilakukan dengan segala perlengkapan, selametan dan pagelaran yang seringkali sukar ditangkap secara rasional dan dalam hal ini kepekaan rasa sangat diperlukan untuk dapat memahami makna simbolik itu.

Kata ruwatan berasal dari kata ruwat, artinya bebas, lepas. Kata mangruwat atau ngruwat artinya membebaska, melepaskan.
Dalam tradisi lama atau kuna yang diruwat adalah makhluk hidup mulia atau bahagia, tetapi berubah menjadi hina dan sengsara. Maka mereka yang hidup sengsara atau hina itu harus diruwat, artinya dibebaskan atau dilepaskan dari hidup sengsara. (Kamajaya,1992:11). Pengertian yang senada juga terdapat pada Kamus Besar Bahasa Indonesia (dalam Kamajaya,1992:11) yang menyebutkan ruwat berarti pulih kembali sebagai keadaan semula atau juga terlepas (bebas) dari nasib buruk yang akan menimpa bagi orang yang menurut kepercayaan akan tertimpa nasib buruk seperti anak tunggal dan sebagainya.

Definisi Ruwatan juga diutarakan oleh Pamungkas (2008:8) yang menyebutkan bahwa ruwatan adalah upacara yang dilakukan untuk menghilangkan dampak yang bisa berbentuk kesialan, menjauhkan segala kemungkinan yang buruk yang bias terjadi jika seseorang termasuk orang yang harus diruwat. Dari beberapa definisi ruwatan tersebut, maka dapat disimpulkan bahwa ruwatan adalah upacara yang dilakukan dalam rangka mencari keberuntungan dan terbebas dari kesialan hidup. Upacara adat ruwatan ini pada umumnya dilakukan oleh masyarakat Jawa. Zairul Haq (2011:4) berpendapat bahwa salah satu ciri masyarakat Jawa adalah bahwa mereka merupakan masyarakat yang begitu percaya terhadap suatu "kekuatan" di luar alam yang mengatasi mereka. Banyak masyarakat Jawa merasa kagum terhadap kejadian-kejadian di sekitar dan fenomenafenomena alam sehari-hari yang kadang sulit difahami dengan rasio.

Ada beberapa tujuan dilakukannya ruwatan, salah satunya seperti yang diungkapkan (Pamungkas,2008:8) yaitu untuk menghilangkan dampak yang bisa berbentuk kesialan, menjauhkan segala kemungkinan yang buruk yang bisa terjadi jika seseorang termasuk yang harus diruwat. Jenis ruwatan ada beberapa, satu diantara yang selama ini dilakukan oleh masyarakat Jawa adalah Ruwatan Murwakala/ Purwakala. Purwa adalah arti dari wayang, jadi ruwatan purwakala itu merupakan ritual dengan menggunakan media wayang. Tetapi di sini penulis tidak meneliti tentang 
ruwatan murwakala melainkan ruwatan bumi, karena selain ruwatan murwakala sudah pernah diteliti sebelumnya, ruwatan murwakala ini sudah terlalu umum dijumpai. Ruwatan bumi merupakan serangkaian prosesi adat yang dilakukan di Kelurahan Winongo Kecamatan Manguharjo Kota Madiun. Ruwatan bumi yang dimaksud adalah dengan memberikan sedekah hasil bumi kepada dewa sebagai upaya agar terhindar dari malapetaka.

2. Perlengkapan dalam Upacara Adat Ruwatan Bumi

Berdasarkan hasil wawancara, ruwatan bumi yang dilaksanakan oleh masyarakat Kelurahan Winongo membutuhkan waktu yang cukup lama dalam hal persiapannya. Hal tersebut dikarenakan terdapat beberapa perlengkapan, antara lain:

\section{a. Menyiapkan Sajen}

Sajen atau sesajian untuk ruwatan bumi ini adalah salah satu syarat penting yang harus disiapkan, karena dianggap sebagai bentuk penghormatan kepada roh nenek moyang.

b. Slametan atau kenduri yang dilakukan dimakam tokoh yang membuka lahan di daerah winpnga atau cikal bakal kelurahan winongo. Slametan ini biasanya hanya dilakukan oleh kaum pria, sementara kaum wanita menyiapkannya.

c. Menghias diri dan rumah

Menghias diri dan rumah bukan merupakan syarat wajib dalam acara ruwatan, namun warga tetap melakukannya karena percaya bahwa sesuatu yang bersih akan menjauhkan dari bala atau kala

d. Kirab sedekah bumi

Kirab yang dilakukan dalam ruwatan bumi ini yaitu dengan membawa hasil bumi yang berupa gunungan kakung yang berisi jajanan pasar dan gunungan estri yang terdiri dari hasil bumi

\section{e. Pagelaran wayang}

Pagelaran wayang dilakukan pada malam hari diacara penutupan ruwatan, lakon yang dimainkan bukan lakon murwakala namun lakon biasa yang disesuaikan dengan kondisi kekinian.

\section{Fungsi Upacara Adat Ruwatan Bumi}

Ada beberapa tujuan dilakukannya ruwatan, salah satunya yaitu untuk menghindarkan diri dari ketidak beruntungan yang datang dari Sang Maha Kala (bencana). Begitu pula fungsi diadakannya ruwatan bumi di kelurahan Winongo menurut Soemadi, bahwa terdapat beberapa fungsi ruwatan bumi, yaitu:

a. Terhindar dari bencana

Masyarakat Kelurahan Winongo percaya, bahwa dengan dilaksanakannya upacara adat ruwatan bumi setiap setahun sekali akan data menghilangkan bala atau bencana, sehingga kehidupannya menjadi tentram.

b. Ungkapan rasa syukur

Ungkapan rasa syukur tersebut diwujudkan dalam bentuk mengarak gunungan kakung dan gunungan putrid yang ditujukan kepada sang pencipta alam dengan harapan hasil bumi masyarakat melimpah

c. Melestarikan tradisi leluhur

Adanya upacara adat ruwatan bumi ini sebagai upaya untuk tetap melestarikan budaya warisan leluhur walaupun saat ini telah berkembang arus globalisasi agar kebudayaan tersebut masih dapat dinikmati oleh anak cucu.

d. Membangun hubungan kekeluargaan dan kebersamaan antar masyarakat

Prosesi upacara adat ruwatan bumi membutuhkan waktu yang lama dan persiapan yang banyak sehingga membutuhkan tenaga, dari situlah timbul interaksi sosisal diantara warga yang dapat menumbuhkan nilai-nilai kekeluargaan dan kebersamaan. (wawancara dengan Bpk.Soemadi/78 tahun, 1 April 2015).

Dengan demikian upacara adat ruwatan bumi adalah suatu prosesi ritual yang dilakukan secara turun temurun pada suatu daerah yang memiliki tujuan sebagai wujud rasa syukur kepada sang pencipta dan membersihkan diri dari segala hal kesialan, ketidak beruntungan, dan terbebas dari kesialan hidup.

\section{B. Nilai-nilai Filosofis}

1. Pengertian Nilai

Nilai adalah kualitas dari sesuatu baik lahir maupun batin. Dalam kehidupan 
manusia, nilai dijadikan landasan, alasan, atau motivasi dalam bersikap dan bertingkah laku baik disadari maupun tidak. Nilai berbeda dengan fakta, dimana fakta dapat diobservasi melalui verifikasi empiris, sedangkan nilai bersifat abstrak yang harus dapat dipahami, dipikirkan, dimengerti, dan dihayati oleh manusia. Nilai berkaitan juga dengan harapan, cita-cita, keinginan, dan sejak sesuatu pertimbangan internal (batiniah) manusia. (Nurcahyo,dkk.2012 :86).

\section{Pengertian Filosofis}

Secara etimologis, kata filsafat berasal dari bahasa Yunani, philosophia yang berarti cinta akan kebijaksanaan, atau cinta akan hikmat, atau cinta akan pengetahuan. Philosophia terdiri dari kata-kata philos yang berarti pecinta atau pencari, dan Sophia yang berarti kebijaksanaan, atau hikmat atau pengetahuan. Sedang kata filsuf (ahli filsafat) diturukan dari kata philosophos. Tradisi kuno menyatakan bahwa penggunaan kedua kata tersebut dalam khasanah ilmu filsafat telah dimulai sejak masa Pythagoras (Daliman,2012:4).

Hal senada juga disampaikan oleh Mulyono (dalam Purwadi, 2005:2) bahwa kata filsafat berasal dari kata majemuk dalam bahasa Yunani, philosophia yang berarti cinta kebijaksanaan. Sedangkan orang yang melakukannya disebut filsuf yang berasal dari kata Yunani Philosopos. Kedua kata itu sudah lama dipakai orang. Dari sejarah telah terungkap bahwa katakata itu sudah dipakai oleh filsuf Sokrates dan Plato pada abad V sebelum Masehi. Seorang filsuf berarti seorang pecinta kebijaksanaan, berarti orang tersebut telah mencapai status adimanusiawi atau wicaksana, waskhita ngerti sadurunge winarah atau jalma limpat seprapat tamat.

Jadi nilai-nilai filosofis adalah segala sesuatu yang memiliki makna atau keyakinan yang berkaitan dengan pandangan hidup seseorang atau sekelompok orang yang merupakan konsep dasar mengenai kehidupan yang dicitacitakan.

\section{Sumber Pembelajaran Sejarah Lokal}

1. Pengertian Sumber Pembelajaran Sejarah Lokal
Sanjaya (2009: 174) menyebutkan "sumber belajar adalah segala sesuatu yang dapat dimanfaatkan oleh siswa untuk mempelajari bahan dan pengalaman belajar sesuai dengan tujuan yang hendak dicapai". Hal yang hampir sama juga disampaikan Dale (dalam Sitepu,2014:18) bahwa "secara singkat, sumber belajar dapat dirumuskan sebagai sesuatu yang dapat dipergunakan untuk mendukung proses belajar.

Pengertian tersebut diatas sejalan dengan makna sumber belajar dalam Dictionary of Instructional Technology (dalam Sitepu,2014:18) yang menyebutkan sumber belajar adalah 'Any resources(people, instructional materials, instructional hardwares, etc) which may be used by a learner to bring abaout or facilitate learning'. Rumusan itu menunjukkan sumber belajar mencakup apa saja termasuk orang, bahan pembelajaran, perangkat keras pembelajaran dan lain-lain yang dapat dipergunakan oleh pemelajar untuk memudahkannya belajar. Pengertian ini tidak memberikan batasan cakupan sumber belajar tetapi memberikan penekanan pada fungsi sumber belajar bagi pemelajar yakni untuk memudahkan terjadinya belajar.

Dari beberapa pengertian tersebut bisa dijelaskan bahwa sumber belajar adalah segala sesuatu yang bisa digunakan untuk menambah pengetahuan demi mencapai tujuan pendidikan. Dalam hal ini bentuk yang digunakan adalah mencakup segala hal yang tersusun secara sistematis dan bisa dijadikan acuan dalam proses pembelajaran

Widja dan Syafrizal (dalam Hanif,2003: 30) menjelaskan bahwa Sejarah lokal merupakan suatu bentuk penulisan sejarah dalam lingkup yang terbatas, yang meliputi suatu lokalitas tertentu, biasanya dikaitkan dengan unsur spasial (ruang dan tempat). Penulisan sejarah lokal di Indonesia diperlukan untuk memahami realitas masa lampau suatu kelompok masyarakat pada tempat tertentu. Sejarah lokal mempelajari actor sejarah yaitu manusia yang sebenarnya(tanpa disarati nilai), bukan manusia yang disarati nilai seperti pahlawan dan pemberontak. Berarti sejarah lokal membicarakan masa lampau suatu masyarakat, berupa struktur dan proses 
tindakan manusia guna memahami fenomena tertentu dengan melihat konteks sosiokultural. Berbeda halnya dengan sejarah nasional yang bersifat consensus untuk tuntutan ideologis guna memenuhi kesatuan nasional.

Pengertian tersebut senada dengan pendapat Priyadi (dalam Priyadi,2012:171) yang menyebutkan bahwa ruang sejarah lokal merupakan lingkup geografis yang dapat dibatasi sendiri oleh sejarawan dengan alas an yang dapat diterima semua orang. Mazhab Leicester menyatakan bahwa sejarah lokal adalah asal-usul, pertumbuhan, kemunduran, dan kejatuhan dari kelompok masyarakat lokal. Mazhab tersebut memang mengaitkan sejarah lokal dengan kemunduran dan kejatuhan, meskipun pada dasarnya sejarah mengalami perubahan, baik mengarah ke kemajuan maupun kemunduran dan kejatuhan. Kisah kelampauan dari kelompok atau kelompokkelompok masyarakat yang diikat oleh kesatuan etniskultural pada daerah geografis yang terbatas atau tertentu, atau dibatasi sendiri oleh penelitinya itulah yang menjadi bahan perhatian sejarawan lokal.

Hal tersebut diperkuat oleh pendapat (Supardi. 2011:49) yang menyebutkan bahwa sejarah lokal (local history) artinya sejarah yang mengkaji tentang kehidupan manusia dalam ruang terbatas. Batasan sejarah lokal tidak mempedulikan batasan administratif, dengan demikian bisa saja sebuah desa (sejarah pedesaan), sejarah kota, sejarah beberapa desa menjadi kajian sejarah lokal. Dengan demikian, yang dimaksud sejarah lokal adalah segala sesuatu peristiwa sejarah yang menjadi dasar dari identitas nasional dan memiliki karakteristik tersendiri karena adanya batasan oleh ruang atau tempat, jadi bisa menghubungkan sejarah setempat dengan sejarah yang lebih luas.

\section{Metode Penelitian}

Jenis penelitian yang dilakukan yaitu jenis penelitian kualitatif deskriptif. Bagian deskriptif dalam catatan data ini meliputi potret subjek, rekonstruksi dialog, deskripsi keadaan fisik, struktur tentang tempat, dan barang-barang lain yang ada di sekitarnya. Demikian juga, catatan tentang berbagai peristiwa khusus (termasuk siapa yang terlibat dengan cara bagaimana, gerakgeriknya, dan juga tingkah laku atau sikap penelitiannya) (Sutopo, 2002: 74).

\section{Hasil Penelitian}

Upacara adat ruwatan bumi di Kelurahan Winongo Kota Madiun ini adalah kegiatan yang berlangsung secara turun temurun sejak jaman kerajaan Mataram yang merupakan sebuah cara untuk menghindarkan diri maupun wilayah dari gangguan-gangguan maupun malapetaka. Ada faktor yang menyebabkan warga masyarakat Winongo tetap melaksanakan kegiatan tersebut meskipun perkembangan jaman telah maju, diantaranya adalah takut celaka dan bentuk penghormatan kepada Yuhan yang Maha Esa, serta pelestarian kebudayaan yang telah diwariskan oleh nenek moyang mereka. Makna ruwatan sendiri memiliki pengertian yaitu membersihkan diri dan lingkungannya sehingga diharapkan akan terbebas dari malapetaka.

Dalam hal ini, upacara adat ruwatan bumi juga memiliki fungsi seperti terhindardari bencana, ungkapan rasasyukur, melestarikan tradisi leluhur, serta membangun hubungan kekeluargaan dan kebersamaan antar masyarakat. Ditengah kemajuan peradaban jaman, masyarakat tetap harus melsestarikannya. Kegiatan upacara adat ruwatan bumi ini memiliki nila-nilai filosofis, dalam gambaran umum, ruwatan bumi memiliki nilai filosofis yaitu agar kita selalu menjaga keseimbangan alam, kebersihan lingkungan, kebersihan diri, serta selalu melestarikan warisan nenek moyang kita, serta wujud rasa syukur terhadap apa yang telah diberikan oleh Tuhan Yang Maha Esa. disisi lain upacara adat ruwatan bumi juga memiliki perlengkapan yang harus disiapkan dan memiliki makna dan nilai filosofis tersendiri, diantaranya:

1. Sesajen

Sesajen adalah merupakan seserahan atau sesajian yang diperuntukkan bagi 
keberadaan roh-roh leluhur karena diangap disukai olehnya,dan ditaruh ditempattempat tertentu dalam upacara adat ruwatan bumi tersebut yang isi dari sesajen tersebut adalah kembang boreh, kembang setaman, menyan, cok bakal, kelopo wutuh pitu, kembang kenongo, dan ayam jago yang dipanggang.

2. Buceng

Nasi yang dibentuk kerucut kecil yang berisi lalapan, lauk-pauk, urap, ditaruh diatas daun pisang dipergunakan saat nyekar atau melekkan di makam sesepuh. "buceng" mlebu kenceng, artinya jika kita punya rejeki diharapkan kita bisa berhemat. Sebagai manusia kita tidak dibolehkan hidup berfoya-foya dan mengumbar harta.

3. Tumpeng

Terdapat 2 tumpeng besar yang biasanya diarak dalam prosesi upacara adat ruwatan bumi ini, yaitu tumpeng lanang dan tumpeng estri, tumpeng lanang yang isinyahasil bumi sebagai perlambang bahwa lelaki harus menafkahi istrinya, dan tumpeng estri yang berisi nasi dan lauk pauk yang melambangkan bahwa wanita harus bisa memmasak dan menata rumah sebagai kewajibannya.

4. Siraman

Siraman yang dilakukan di sumur yang dituakan diwilayah Winongo yaitu menyiramkan air dari kepala hingga kaki yang dimana air tersebut diberi bunga 7 macam yang memiliki makna membersihkan diri dan harapan agar amal perbuatan kita selalu baik sehingga kita selalu terhindar dari malapetaka

5. Kirab Sedekah Bumi

Kirab ini membawa dua gunungan atau tumpeng besar yang telah dibuat, yaitu gunungan estri dan gunungan jaler dan diiringi dongkrek dan berdandan seperti karnaval, kirab ini bermakna ungkapan syukur terhadap limpahan rahmat Tuhan. Didalam kirab sendiri juga terdapat Dongkrek yang merupakan kesenian khas dari Madiun

6. Wayangan

Pertunjukkan wayang adalah acara puncak dari prosesi upacara adat ruwatan bumi di Winongo, dalang yang digunakan pun adalah dalang khusus ruwat, selain itu cerita yang diangkatpun biasanya juga berhubungan dengan ruwatan, dan dilakukan semalam suntuk sebagai penutup seluruh rangkaian upacara adat ruwatan bumi.

Dalam hal ini, upacara adat ruwatan bumi juga memiliki potensi sebagai sumber pembelajaran sejarah lokal, dikatakan memiliki potensi karena didalam upacara adat ruwatan bumi ini terdapat banyak wawasan dan pengetahuan tentang asal usul suatu kebudayan daerah, dalam hal ini budaya lokal. Asal-usul daerah tersebut, kebudayaannya, nilai-nilai filosofis dari upacara tersebut. Wawasan inilah yang bisa dihubungkan dengan pembelajaran sejarah lokal yang ada di dunia pendidikan, agar generasi muda mampu memahami sejarah dan budaya lokal yang dia miliki.

Potensi sumber pembelajaran lokal inilah yang diharapkan mampu membuat generasi muda sadar dan ikut melestarikan kebudayaan yang telah diwariskan oleh nenek moyangnya. Karena dengan bisa dijadikannya upacara ruwatan bumi ini sebagai sebagai sumber pembelajaran local akan menambah pengetahuan anak didik akan pentingnya memahami sejarah local yang mereka miliki.

\section{Pembahasan}

Salah satu tradisi yang hingga saat ini masih dilestarikan oleh masyarakat Jawa tradisional adalah upacara adat ruwatan bumi. Ruwatan bumi tidak hanya mengandung nilai fungsi magis spiritual, tetapi juga mempunyai nilai fungsi sosial untuk mempererat hubungan sesama manusia. Semakin majunya peradaban di era globalisasi seperti saat ini ternyata tidak menyurutkan semangat warga di Kelurahan Winongo Kecamata Manguharjo Kota Madiun untuk terus melestarikan salah satu tradisi kejawen tersebut. Upacara adat ruwatan bumi di wilayah ini digelar setiap tahun sekali pada bulan Suro atau Muharram pada kalender Jawa atau Islam dan dalam hal ini sekitar bulan November . Orang Jawa menganggap bulan Suro sebagai bulan yang suci dan sakral. Kebanyakan dari mereka mengharapkan untuk ngalap berkah dari 
hari besar suci ini. Untuk waktu pelaksanaannya pun juga ada pemilihan harinya agar dalam persiapan maupun pelaksanaan acara tersebut dapat berjalan dengan lancar.

\section{A. Latar Belakang Sejarah Upacara Adat Ruwatan Bumi Di Kelurahan Winongo Kecamatan Manguharjo Kota Madiun}

Upacara adat ruwatan bumi di Kelurahan Winongo Kecamatan Manguharjo Kota Madiun adalah merupakan kegiatan yang telah berlangsung turun-temurun dan diwariskan oleh nenek moyang masyarakat di wilayah ini sejak jaman kerajaan Mataram, karena wilayah Madiun pada saat itu merupakan tanah jajahan atau dalam kekuasaan kerajaan Mataram. Di Kelurahan Winongo ini, ruwatannya bernama ruwatan bumi yang bertujuan untuk membersihkan bumi Winongo dari kesialan sekaligus ungkapan syukur atas segala limpahan hasil bumi.

Upacara adat ruwatan bumi di Kelurahan Winongo Kecamatan Manguharjo Kota Madiun selalu dilaksanakan setiap satu tahun sekali dan selalu meriah disetiap pelaksanaannya, ada faktor-faktor yang menyebabkan masyarakat Winongo terus melestarikan kegiatan tersebut ditengah era globalisasi yang menuntut orang untuk berpikiran logis dari pada mistis yaitu,1). Takut kuwalat, 2). Bentuk penghormatan dan ungkapan syukur kepada Dewi Sri sebagai perantara sang pencipta alam atas hasil bumi. Di lain hal upacara adat ruwatan bumi ini memiliki fungsi sebagai pengingat kepada generasi sekarang tentang warisan kebudayaan dari leluhur yang didalamnya memiliki makna serta membangun hubungan kekeluargaan dan kebersamaan antara masyarakat di Winongo.

Sistem upacara religius bertujuan mencari hubungan manusia dengan Tuhan, dewa-dewa atau makluk halus yang mendiami alam gaib. Sistem upacara merupakan wujud kelakuan atau behavioral manifestation dari religi. Dimana upacara terdiri dari kombinasi dari macam unsur upacara, seperti misalnya: berdoa, bersujud, bersaji, berkorban, makan bersama, menari, dan menyanyi, berprosesi, berseni drama suci, berpuasa, bertapa, dan bersemadi. Dapat diperjelas bahwa setiap unsur yang terkandung dalam upacara selalu diadakan sebagai syarat atau perlengkapan disetiap penyelenggaraan upacara adat

Dalam kegiatan ini, ada prosesi yang harus ada dan disiapkan dengan sungguhsungguh,yaitu:

1. Menyiapkan sesajen

Sesajen adalah syarat yang harus terpenuhi dalam rangkaian upacara adat ruwatan bumi, yang didalamnya berisi kembang boreh, kembang setaman, dupa/menyan, cok bakal, kelopo wutuh 7 , kembang mayang kembar, beras sajimpit, jarik, rencek, kembang kantil, kembang kenongo lan pitik jago jowo dan biasanya diletakkan di sumur yang dikeramatkan dan makam sesepuh

2. Melaksanakan slametan atau kenduri

Melaksanakan kegiatan ini dimakam sesepuh dan biasanya diteruskan dengan melekkan.

3. Siraman

Siraman merupakan salah satu prosesi yang harus dilaksanakan pada acara upacara adat ruwatan bumi. Siraman ini dilakukan di sendang atau warga sekitar lebih mengenalnya dengan sebutan sumur bur. Siraman ini dilakukan dengan air yang telah dicampur dengan bunga 7 macam disiramkan dari kepala hingga kaki.

4. Kirab sedekah bumi

Melaksanakan kirab atau ritual jalan kaki beriringan dengan membawa gunungan dua macam yang dinamakan gunungan kakung dan gunungan estri, gunungan kakung yang berisi nasi tumpeng dan lauk pauk sedangkan gunungan estri yang berisi hasil bumi warga Winongo. Dalam acara kirab ini juga diiringi Dongkrek yang merupakan kesenian khas Madiun.

5. Pagelaran wayang ruwat.

Pagelaran wayang adalah merupakan prosesi penutup upacara adat ruwatan bumi di Winongo, dalang maupun cerita yang ada pun adalah khusus ruwat.

\section{B. Nilai-nilai Filosofis Upacara Adat Ruwatan Bumi}

Nilai adalah kualitas dari sesuatu baik lahir maupun batin. Dalam kehidupan manusia, nilai dijadikan landasan, alasan, 
atau motivasi dalam bersikap dan bertingkah laku baik disadari maupun tidak dan filosofi adalah segala sesuatu yang memiliki makna atau keyakinan yang berkaitan dengan pandangan hidup seseorang atau sekelompok orang yang merupakan konsep dasar mengenai kehidupan yang dicita-citakan, jadi pada dasarnya nilai-nilai filosofi upacara adat ruwatan bumi adalah makna atau nilai yang terkandung dalam upacara adat ruwatan bumi yang dijadikan landasan atau acuan hidup sekelompok orang.

Dalam upacara adat ruwatan bumi di Kelurahan Winongo Kecamatan Manguharjo Kota Madiun bahwa nilai filosofis yang dapat diambil dari upacara tersebut bahwa sebagai manusia kita diwajibkan untuk selalu saling hormat-menghormati, terlebih kepada leluhur kita. Selain itu kita juga harus selalu bersyukur atas apa yang kita peroleh. setiap prosesi kegiatan maupun perlengkapan yang digunakan juga memiliki nilai-nilai filosofis yang terkandung didalamnya. Seperti halnya dalam prosesi upacara adat ruwatan bumi, yaitu :

1. Sesajen

Sesajen berarti sesajian yang memiliki makna bahwa kita harus selalu hormat kepada nenek moyang dengan cara memberikan persembahan

2. Slametan

Berasal dari bahasa Jawa slamet yaitu permohonan keselamatan dalam kehidupan dengan cara do'a yang dipanjatkan kepada Tuhan Yang Maha Esa atau Sang pencipta.

\section{Siraman}

Pengertian siraman atau menyiramkan air ke tubuh yang memiliki nilai yaitu agar kita tersucikan dari dosa kehidupan. Airnya juga diberi bunga tujuh rupa agar harum, dalam artian segala amal perbuatan kita harus selalu baik

4. Kirab sedekah bumi

Kirab yang didalamnya membawa hasil bumi dan juga lauk pauk ini memiliki nilai bahwa kita harus bekerja keras dalam kehidupan kita sehari-hari.

Selain nilai-nilai filosofi yang terkandung secara umum dalam upacara adat ruwatan bumi beserta prosesinya, dalam hal ini ada nilai-nilai filosofis yang terkandung dalam perlengkapan maupun alatyang digunakan didalamnya, seperti :

1. Buceng

Berasal dari dua suku kata yaitu mlebu kenceng artinya jika seseorang telah mencari rejeki dengan susah payah, maka dia harus mampu berhemat dan tidak menghamburhamburkan hartanya itu.

2. Tumpeng

Singkatan dari metu sing mempeng atau keluar dengan rajin artinya bahwa kita sebagai manusia harus rajin dan tekun dalam bekerja.

3. Gunungan estri

Tumpeng dan lauk-pauknya, yang memiliki nilai filosofis bahwa seorang perempuan harus tahu tugas dan kewajibannya dalam rumah tangga seperti memasak

4. Gunungan Jaler

Gunungan yang berisi hasil bumi yang memiliki nilai filosofi bahwa laki-laki haruslah bertanggung jawab menafkahi istrinya

5. Pitung pasang dalam siraman

Pitung atau pitu yang memiliki nilai filosofis agar warga Winongo senantiasa mendapat pitulungan dari yang Tuhan Yang Kuasa.

Selain makna atau nilai-nilai filosofi yang terkandung di dalamnya, upacara adat ruwatan bumi di Kelurahan Winongo Kecamatan Manguharjo Kota Madiun juga memiliki fungsi yaitu nguri-nguri budoyo jawi atau melestarikan budaya Jawa ditengah era globalisasi seperti saat ini, suatu budaya yang merupakan warisan nenek moyang kita yang telah dijalankan secara turun temurun sehingga tidak akan pudar disaat jaman semakin maju dan masyarakat lebih banyak berfikiran logis.

\section{Potensi Upacara Adat Ruwatan Bumi \\ Di Kelurahan Winongo Kecamatan Manguharjo Kota Madiun Sebagai Sumber Pembelajaran Sejarah Lokal}

Sumber pembelajaran adalah segala sesuatu, baik itu fisik maupun nonfisik yang bisa digunakan sebagai materi dalam proses menyampaikan pengetahuan demi tercapainya tujuan pendidikan, hal itu sesuai dengan pernyataan Sanjaya (2009: 174) yang menyebutkan "sumber belajar adalah 
segala sesuatu yang dapat dimanfaatkan oleh siswa untuk mempelajari bahan dan pengalaman belajar sesuai dengan tujuan yang hendak dicapai ". Hal yang hampir sama juga disampaikan Dale (dalam Sitepu,2014:18) bahwa "secara singkat, sumber belajar dapat dirumuskan sebagai sesuatu yang dapat dipergunakan untuk mendukung proses belajar.

Widja dan Syafrizal (dalam Hanif,2003: 30) menjelaskan bahwa Sejarah lokal merupakan suatu bentuk penulisan sejarah dalam lingkup yang terbatas, yang meliputi suatu lokalitas tertentu, biasanya dikaitkan dengan unsur spasial (ruang dan tempat). Berarti sejarah lokal membicarakan masa lampau suatu masyarakat, berupa struktur dan proses tindakan manusia guna memahami fenomena tertentu dengan melihat konteks sosiokultural yang terjadi pada suatu wilayah lokal, berbeda halnya dengan sejarah nasional yang bersifat consensus untuk tuntutan ideologis guna memenuhi kesatuan nasional.

Diketahui pula sejarah lokal merupakan sebuah disiplin ilmu, yang harus meninjau aspek-aspek metodologinya. Dilihat dari sifat pendekatan obyek dan wujud penggambaran peristiwanya, sejrah lokal juga bersifat tradisional dan bersifat akademik, akan tetapi tergantung dari tujuan, dan latar belakang dari penulisan sejarah lokal itu sendiri. Upacara adat ruwatan bumi di Kelurahan Winongo Kecamatan Manguharjo Kota Madiun bisa dikatakan masuk kedalam sumber pembelajaran sejarah lokal tradisional karena didalam upacara tersebut juga memiliki cerita tentang keberadaan sejarah suatu wilayah yang didalamnya terdapat peristiwa yang dialami suatu keompok masyarakat pada suatu daerah tertentu di masa lampau, dalam hal ini masyarakat Winongo.

Kegiatan belajar mengajar tidak hanya dilakukan di dalam kelas, namun bisa juga dilakukan di luar kelas misalnya berkunjung ke tempat-tempat bersejarah, ke museum, atau ke laboratorium. Khusus mata pelajaran IPS/sejarah perlu kegiatan belajar mengajar yang dilaksanakan di luar sekolah supaya terjadi kegiatan belajar mengajar yang menarik. Selain itu kalau kita belajar sejarah harus ada buktinya, karena kalau tidak ada buktinya bukan dikatakan sejarah. yang dimaksud sebagai bukti itu bisa diartikan sebagai jejak-jejak peninggalannya, seperti bangunan, fosil, foto, surat, maupun rekaman video.

Ditinjau dari beberapa aspek yang ada, baik itu yang berkaitan dari hasil wawancara maupun hasil otentik yang berupa foto ataupun makna yang terkandung dari upacara ada truwatan bumi di Kelurahan Winongo Kecamatan Manguharjo Kota Madiun, ada potensi bahwa kebudayaan yang telah berlangsung bertahun-tahun di wilayah ini bisa digunakan sebagai materi tambahan dalam pembelajaran sejarah lokal dengan materi perkembangan Hindu-Budha di Indonesia dengan standard kompetensi 5. (memahami perkembangan masyarakat sejak masa Hindu-Budha sampai sekarang) dan Kompetensi dasar 5.1 (mendekripsikan perkembangan mayarakat, kebudayaan, dan pemerintahan pada masa Hindu-Budha serta peninggalan-peninggalannya) pada siswa kelas VII semester II. Ini sesuai bahwa kebudayaan yang telah berlangsung lama di wilayah Winongo ini adalah juga merupakan peninggalan dari kerajaan mataram yang notabene bercorak Hindu.

Diharapkan juga dengan adanya potensi dari upacara tersebut bagi sumber pembelajaran sejarah lokal, peserta didik akan tahu tentang sejarah lokalnya serta segala sesuatu yang terdapat didalamnya, seperti ungkapan yang didapat dalam wawancara, mosok wong jowo ra njowo atau masak orang Jawa tidak tahu, atau dapat diartikan sebagai sindiran tentang ketidaktahuan masyarakat Jawa terhadap budayanya sendiri. Dengan wawasan yang didapat oleh peserta didik tersebut, nantinya mereka juga akan tergerak untuk terus melestarikan kebudayaan yang merupakan warisan dari nenek moyang mereka

\section{Penutup}

\section{A. Simpulan}

Berdasarkan paparan data, temuan penelitian, dan pembahasan yang telah 
disampaikan dimuka maka dapat disimpulkan sebagai berikut:

Upacara adat ruwatan bumi di Kelurahan Winongo Kecamatan Manguharjo Kota Madiun adalah tradisi Jawa yang merupakan peninggalan kerajaan Mataram yang notabene bercorak Hindu. Ini dikarenakan wilayah Madiun adalah daerah kekuasaan Mataram pada masa itu. Kegiatan ini terus berlangsung dan dilestarikan oleh masyarakat Winongo setiap tahun sekali, ada beberapa faktor sehingga warga terus melestarikan kegiatan tersebut ditengah era globalisasi yang menuntut orang untuk berpikiran logis dari pada mistis yaitu,1). Takut kuwalat atau terkena kutukan, 2). Bentuk penghormatan dan ungkapan syukur kepada Dewi Sri sebagai perantara sang pencipta alam atas hasil bumi. Upacara adat ruwatan bumi di Winongo ini biasanya dilangsngkan pada bulan suro pada penanggalan Jawa.

Ada beberapa nilai-nilai filosofis yang terkandung didalam upacara adat ruwatan bumi di Kelurahan Winongo Kecamatan Manguharjo Kota Madiun, secara umum yaitu ruwatan ini bermakna resik-resik atau membersihkan baik itu diri, tempat tinggal maupun lingkungan. Didalam ruwatan sendiri terdapat prosessi atau pelaksanaan dan juga perlengkapan yang juga memiliki namun pada dasarnya adalah ungkapan rasa syukur, kemauan bekerja keras, kebijaksanaan dalam menggunakan rejeki yang didapat, penyucian diri dari dosa, tanggung jawab suami maupun istri, permhonan pertolongan dan keselamatan kepada sang pencipta.

Selain makna atau nilai-nilai filosofi yang terkandung di dalamnya, upacara adat ruwatan bumi di Kelurahan Winongo Kecamatan Manguharjo Kota Madiun juga memiliki fungsi yaitu nguri-nguri budoyo jawi atau melestarikan budaya Jawa ditengah era globalisasi seperti saat ini, suatu budaya yang merupakan warisan nenek moyang kita yang telah dijalankan secara turun temurun sehingga tidak akan pudar disaat jaman semakin maju dan masyarakat lebih banyak berfikiran logis.
Nilai-nilai atau makna yang terdapat dalam upacara adat ruwatan bumi di Kelurahan Winongo Kecamatan Manguharjo Kota Madiun dimungkinkan mampu dijadikan suber pembelajaran sejarah lokal yaitu pelajaran IPS, karena didalamnya memiliki wawasan tentang sejarah wilayah dan terdapat peristiwa yang dialami suatu keompok masyarakat pada suatu daerah tertentu di masa lampau, dalam hal ini masyarakat Winongo. Sehingga diharapkan nantinya generasi muda dalam hal ini peserta didik juga mau melestarikan kebudayaan peninggalan nenek moyang tersebut.

\section{B. Saran}

Berdasarkan penelitian yang telah dilaksanakan, dalam hal ini peneliti sekaligus insan akademis memiliki saran bagi beberapa pihak, yaitu :

1. Masyarakat Kelurahan Winongo

Bagi warga Kelurahan Winongo diharapkan terus melestarikan kebudayaan yang merupakan peninggalan dari nenek moyang dan kebersamaan antar warga masyarakat selalu terjaga dengan adanya kegiatan tersebut.

2. Pemerintah Kelurahan Winongo

Agar pemerintah Kelurahan Winongo juga ikut mendukung kegiatan tersebut baik materil dan spirituil, sehingga kebudayaan lokal yang dimiliki wilayah Winongo mampu terus dilaksanakan setiap tahun dan berlangung ecara meriah

3. Pemerintah Kota Madiun

Keberadaan upacara adat ruwatan bumi ini diharapkan mampu dijadikan oleh pemerintah kota Madiun sarana wisata lokal sehingga mampu menjadikan acara tersebut dikenal banyak pihak, karena keberadaannya yang ada dikota.

4. Guru Mata Pelajaran IPS/Sejarah

Peneliti berharap kepada seluru guru mata pelajaran IPS/Sejarah haruslah lebih kreatif dalam melaksanakan kegiatan belajar mengajar agar siswa senang belajar sejarah. Seorang guru juga harus pandai dan cermat dengan lingkungan sekitarnya, karena sejarah lokal itu perlu diajarkan kepada peserta didik baru kemudian sejarah nasional dan lain sebagainya. 
5. Program Studi Sejarah IKIP PGRI MADIUN Diharapkan ada penelitian-penelitian tentang sesuatu hal yang berhubungan dengan sejarah lokal, sehingga dengan banyaknya porsi yang mengangkat tentang tema penelitian tersebut, akan menjadi tambahan referensi tentang wawasan sejarah lokal.

\section{Daftar Pustaka}

Daliman., A. 2012. Pengantar Filsafat Sejarah. Yogyakarta: Ombak.

Hanif, M. 2003. Otonomi Daerah dan Sejarah Lokal Dalam Perspektif Pengajaran Sejarah. Jurnal Pedidikan. 9 (1): 3031

Haq, M. Z. 2011. Mutiara Hidup Manusia Jawa. Yogyakarta: Aditya Media Publishing.

Kamajaya,dkk. 1992. Ruwatan Murwakala. Yogyakarta: Duta Wacana University Pers.

Milles, M B dan Hubberman, A M.1992. Analisis Data Kualitatif: Buku Sumber Tentang Metode-Metode Baru. Terjemahan oleh Rohidi. T R. Jakarta: UI-Press

Moleong, L. J. 2012. Metodologi Penelitian Kualitatif. Bandung: PT Remaja Rosdakarya

Nazir, Moh. 2009. Metode Penelitian. Jakarta: Ghalia Indonesia.

Nurcahyo, dkk. 2012. Ilmu Sosial dan Budaya Dasar. Madiun: Institut Pers IKIP PGRI Madiun.

Pamungkas, R. 2008. Tradisi Ruwatan. Yogyakarta: Narasi

Priyadi., S. 2012. Sejarah Lokal:Konsep, Metode, dan Tantangannya. Yogyakarta: Ombak.

Purwadi., 2005. Upacara Tradisional Jawa. Yogyakarta: Pustaka Pelajar.

Sanjaya., W. 2009. Strategi Pembelajaran Berorientasi Standar Proses Pendidikan. Jakarta: Kencana Prenada Media Group.

Satoto, H., 2008. Simbolisme Jawa. Yogyakarta: Ombak.

Silalahi, G. A. 2003. Metodologi Penelitian dan Studi Kasus. Sidoarjo: CV. Citramedia.
Sitepu, B.P., 20014. Pengembangan Sumber Belajar.Jakarta; PT RajaGrafindo Persada.

Sugiyono. 2008. Metode Penelitian Kuantitatif, Kualitatif, dan $R \& D$. Bandung: Alfabeta.

Sugiyono. 2012. Metode Penelitian Pendidikan (Pendekatan Kuantitatif, Kualitatif, dan R\&D). Bandung: Alfabeta.

Sukmadinata, N. S. 2011. Metode Penelitian Pendidikan. Bandung: PT. Remaja Rosdakarya.

Supardi., 2011. Dasar-dasar Ilmu Sosial.Yogyakarta: Ombak.

Sutopo, H. B. 2002. Metodologi Penelitian Kualitatif. Surakarta: Sebelas Maret Univesity Pers.

Umar., H. 2011. Metode Penelitian untuk Skripsi dan Tesis Bisnis. Jakarta Utara: PT. RajaGrafindo.

Zulianti dan Hanif.. 2012. Simbolisme Grebeg Suro di Kabupaten Ponorogo. Agastya Jurnal Sejarah dan Pembelajaran. Madiun: Prodi Pendidikan Sejarah IKIP PGRI MADIUN. 